\title{
УЛЬТРАЗВУКОВАЯ ДИАГНОСТИКА ЖЕРЕБОСТИ, МОНИТОРИНГ ФИЗИОЛОГИЧЕСКОГО СОСТОЯНИЯ КОБЫЛ
}

\author{
F.A. Benkhadir, L.A. Gnezdilova, D.I. Lazarev
}

\section{ULTRASOUND DIAGNOSIS OF PREGNANCY, MONITORING OF MARES' PHYSIOLOGICAL STATE}

Бенкхадир Фарук Ахмед - асп. каф. диагностики болезней, терапии, акушерства и репродукции животных Московской государственной академии ветеринарной медицины и биотехнологии - МВА им. К.И. Скрябина, г. Москва.

E-mail: lag22004@mail.ru

Гнездилова Лариса Александровна - д-р ветеринар. наук, проф., зав. каф. диагностики болезней, терапии, акушерства и репродукции животных Московской государственной академии ветеринарной медицины и биотехнологии - МВА им. К.И. Скрябина, г. Москва.

E-mail: lag22004@mail.ru

Лазарев Дмитрий Иванович - канд. с.-х. наук, науч. сотр. Центра репродукции лошадей ООО «Хартли Хорс Хаус», Московская обл., Шаховской р-н, д. Стариково.

E-mail: lag22004@mail.ru

Представлены результаты комплексной оценки системы содержания кобыл в центре репродукции «Хартли Хорс Хаус» (Московская область); мониторинга их состояния после осеменения и ультразвуковой диагностики жеребости. Животные содержатся в хороших санитарно-гигиенических условиях: температура воздуха в помещении $4-5{ }^{\circ} \mathrm{C}$, относительная влажность воздуха $75 \%$; скорость движения воздуха - 0,3 м/с, освещенность 150 ЛК. Качество корма по основным параметрам соответствует средним показателям нормы, за исключением несколько повышенного содержания клетчатки. В результате исследования крови жеребых кобыл установлено повышение количества эозинофилов в среднем в групnе до $7 \pm 1,85 \%$ и некоторое снижение показателя сегментоядерных нейтрофилов - в среднем в групnе до $39 \pm 2,21 \%$. Все биохимические показатели сыворотки крови кобыл в первый период жеребости находились в пределах физиологических
Benkhadir Farouk Ahmed - Post-Graduate Student, Chair of Diagnosis of Diseases, Therapy, Obstetrics and Reproduction of Animals, Moscow State Academy of Veterinary Medicine and Biotechnology - MVA named after K.I. Scriabin, Moscow.

E-mail: lag22004@mail.ru

Gnezdilova Larisa Alexandrovna - Dr. Veterinary Sci., Prof., Head, Chair of Diagnosis of Diseases, Therapy, Obstetrics and Reproduction of Animals, Moscow State Academy of Veterinary Medicine and Biotechnology - MVA named after K.I. Scriabin, Moscow.

E-mail: lag22004@mail.ru

Lazarev Dmitry Ivanovich - Cand. Agr. Sci., Staff Scientist, Center of Reproduction of Horses, JSC "Hartley Horse House', Moscow Region, Shakhovskoy District, V. Starikovo.

E-mail: lag22004@mail.ru

норм, за исключением увеличения уровня щелочной фоосфатазы в сыворотке крови до $411,71 \pm 22,28$ ед/л. Ультразвуковой мониторинг жеребости кобыл показал возможность проведения контроля его результативности: через 14-16 дней после осеменения плодное яйцо размером 15 мм визуализируется в правом роге матки; через 30 дней после осеменения визуализируется развивающийся эмбрион. На 65-70-й день после осеменения с точностью до $90 \%$ возможно определить пол будущего жеребенка. В целях более успешной организации воспроизводства лошадей в центрах репродукции необходимо проводить комплексную оценку содержания, кормления кобыл с анализом структуры рациона и качества кормов, оценивать клинический статус животных после осеменения, применять метод трансректальной визуальной эхографрии для ранней диагностики жеребости и морфометрической и фуннкциональной оценки развития зародыша. 
Ключевые слова: кобылы, воспроизводство, ультразвуковая диагностика, мониторине.

The results of complete evaluation of the mare keeping system at the Hartley Horse House' breeding center, Moscow Region, the monitoring of their condition after insemination and the diagnosis by ultrasound of gestation are presented. The animals are kept in good sanitary and hygienic conditions: indoor air temperature is $4-5{ }^{\circ} \mathrm{C}$, relative air humidity - $75 \%$, air movement speed $0.3 \mathrm{~m} / \mathrm{s}$, the illumination - $150 \mathrm{LX}$. The quality of the feed according to the main parameters corresponds to the average standard with the exception of slightly increased fiber content. As a result of blood tests on pregnant mares an increase in the number of eosinophils has been found, - on average in the group $-7 \pm 1.85 \%$ and slight decrease in segmented neutrophil index - on average in the group - $39 \pm 2.21 \%$. All biochemical parameters of the blood serum of the mares in the first gestation period are in accordance with physiological norms, except for an increase in the level of alkaline phosphatase in the blood serum - $417.11 \pm 22.28 \mathrm{u} / \mathrm{l}$. Ultrasound surveillance of mares gestation has shown the possibility of monitoring its performance: 14-16 days after insemination, a $15 \mathrm{~mm}$ fetal egg is visualized in the right uterine horn; 30 days after the insemination, a developing embryo is visualized. On the 65-70th day after the insemination, it is possible to determine the sex of the future foal with an accuracy of $90 \%$. For more effective organization the reproduction of horses in the breeding centers, it is necessary to carry out a complete evaluation of keeping and feeding the mares with an analysis of the structure of the diet and feed quality, to assess clinical condition of animals after the insemination, to use the method of transrectal ultrasound for early diagnosis of gestation and morphometric and functional embryonic development.

Keywords: mares, reproduction, ultrasonic diagnostics, monitoring.

Введение. Всестороннее повышение качества лошадей и улучшение их воспроизводительной способности являются важными задачами коневодства [1, 2]. Повысить эфффективность воспроизводства возможно совершенствованием организационных форм биотехники репродукции, комплексной системы мониторинга фризиологического состояния и ранней диагностики жеребости кобыл [3, 4]. Существенному повышению результативности осеменения способствуют исследования физиологических особенностей репродуктивной системы кобыл, фолликулогенеза и овуляции, оплодотворения и раннего эмбриогенеза у лошадей [5].

Цель исследований. Проведение комплексной оценки содержания кобыл в центре репродукции, мониторинг их состояния после осеменения и ультразвуковая диагностика жеребости.

Задачи: оценить условия содержания и кормления кобыл в центре репродукции; провести комплексный мониторинг состояния кобыл после осеменения по результатам исследования крови и ультразвуковой диагностики.

Материалы и методы исследований. Исследования проводились в 2019 г. в центре репродукции лошадей «Хартли Хорс Хаус», Московская область, Россия. Объектом исследования послужили кобылы ганноверской породы возраста от 4 до 15 лет. Под наблюдением находилось 7 животных. Для оценки состояния жеребых кобыл применяли клинические, акушерско-гинекологические исследования, УЗИ. Проводили гематологические, биохимические исследования сыворотки крови, анализ рациона кормления.

Результаты и их обсуждение. В центре репродукции использовали метод искусственного осеменения кобыл свежеполученной спермой жеребцов. Проводили клинические и акушерскогинекологические исследования животных. С помощью аппарата MyLab ${ }^{\text {TM}}$ DeltaVET компания «Esaote» проводили УЗИ-мониторинг овуляции у кобыл (каждые 6 часов, при приближении момента овуляции - через 3 часа) и жеребости. Кровь исследовали с помощью автоматического биохимического анализатора EOC Bravo 200, гематологического анализатора HemaScreen Vet и PCE-90 Vet.

Анализ условий содержания кобыл показал соответствие их санитарно-гигиеническим требованиям: помещения внутри конюшни сухие, светлые, хорошо вентилируемые, без сквозняков. Температура в помещении находится в пределах $4-5{ }^{\circ} \mathrm{C}$, относительная влажность воздуха $75 \%$, скорость движения воздуха - 0,3 м/с, освещенность - 150 ЛК. 


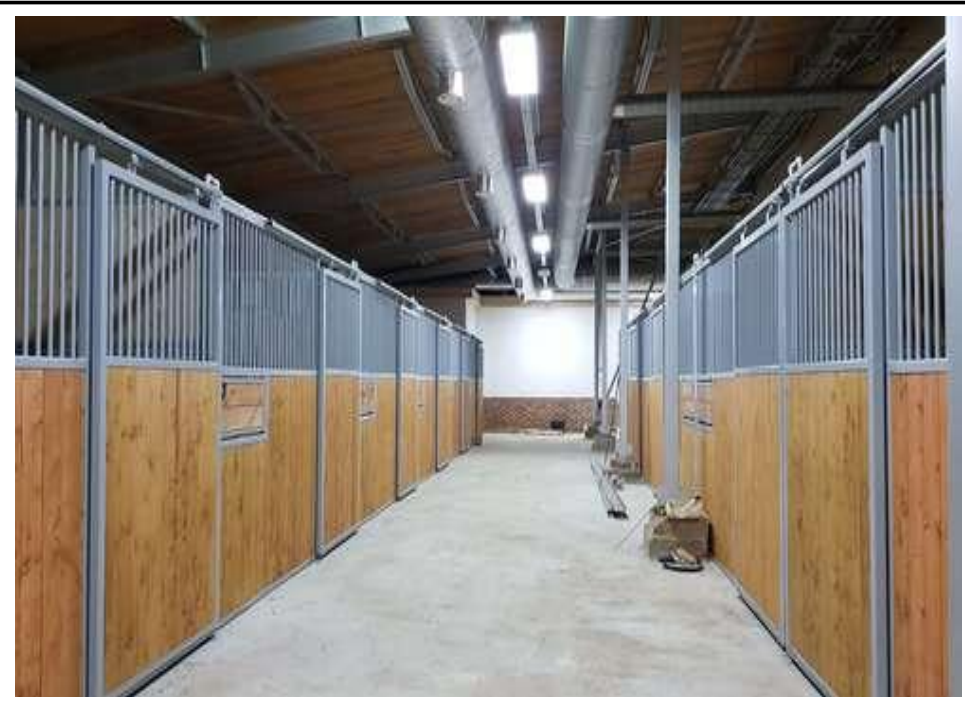

Puс. 1. Условия содержания кобыл

Анализ рациона кормления кобыл. Жеребые кобылы ежедневно получали разнотравное сено, овес, отруби пшеничные, мюсли. Установлено некоторое несоответствие состава рациона и питательности корма Terra nova «Мюсли лошадей» АПК «Новая земля» для кобыл в указанный период их фризиологического состояния. При анализе рациона кормления кобыл до осеменения был установлен несколько повышенный процент обеспеченности рациона по сырому и переваримому протеину, каротину, кальцию, железу и пониженный процент обеспеченности по фоссрору, меди, кобальту, йоду, витамину Д.

Несбалансированное кормление (недостаток или излишек отдельных ингредиентов кормового рациона) может отрицательно влиять на способность кобыл к оплодотворению и на нормальное развитие плода, а также стать основной причиной алиментарного бесплодия [6]. Перед осеменением кобыл рацион был сбалансирован по основным питательным веществам.

Анализ качества кормов кобыл показал следующее. Установлено содержание: в 1 кг сена злакового разнотравного (темного) - 141 г влаги, 859 г сухого вещества, 84 г протеина, 26 г жира, 279 г клетчатки. В 1 кг сена злакового разнотравного (светлого) - 138 г влаги, 862 г сухого вещества, 90 г протеина, 27 г жира, 268 г клетчатки. В 1 кг зерна овса - 153 г влаги, 847 г сухого вещества, 100 г протеина, 41 г жира, 99 г клетчатки. В 1 кг отрубей пшеничных - 147 г влаги, 853 г сухого вещества, 144 г протеина, 40 г жира, 85 г клетчатки. В 1 кг мюсли - 116 г влаги, 884 г сухого вещества, 122 г протеина, 48 г жира, 128 г клетчатки. Анализ показал соответствие параметров средним показателям нормы за исключением несколько повышенного содержания клетчатки в кормах, что может снижать переваримость питательных веществ корма.

Гематологические показатели. В процессе работы установлено, что средние значения гематологических показателей у кобыл в группе в целом соответствовали норме. Количество лейкоцитов - 10,91 \pm 0,64 109/л; количество эритроцитов $8,71 \pm 0,431012 / \pi ;$ уровень гемоглобина $90,14 \pm 6,27 \quad$ г/л; показатель СОЭ 44,0 $\pm 0,82 \mathrm{~mm} / 4$; показатель гематокрита $42,46 \pm 2,12 \%$. Несколько снижен был средний показатель количества тромбоцитов $170 \pm 16,86$ 109/л. Анализ лейкоцитарных фрормул кобыл показал увеличение показателя эозинофилов у животных, который составил в среднем в группе $7 \pm 1,85 \%$, и некоторое снижение показателя сегментоядерных нейтросрилов - в среднем в группе $39 \pm 2,21 \%$. По нашему мнению, это может быть связано с пищевой гиперчувствительностью в ранний период жеребости кобыл.

Биохимический анализ крови. Ууровень общего белка - 73,56 $\pm 2,63$ г/л; альбуминов $39,09 \pm 1,27$ г/л; глюкозы - 3,61 \pm 0,22 ммоль/л; амилазы - 3,71 \pm 0,7 ед/л, АЛТ - 2,25 \pm 16,38 ед/л; АСТ - $372 \pm 63,77$ ед/л; билирубина общего $30,33 \pm 4,9$ ммоль/л; билирубина прямого $8,04 \pm 1,0$ ммоль/л; мочевины - 4,86 \pm 0,16 ммоль/л; креатинина - 117,14 $\pm 22,28$ ммоль/л; 
щелочной фосфратазы - 411,71 \pm 22,28 ед/л; холестерина - 2,36 \pm 0,09 ммоль/л. Все биохимические показатели сыворотки крови кобыл в первый период жеребости находились в пределах фризиологических норм, за исключением увеличения уровня щелочной фосфратазы в сыворотке крови до 411,71 $\pm 22,28$ ед/л.

Ультразвуковой мониторинг жеребости кобыл. Зародышевый пузырек (бластоциста) начинает визуализироваться в виде эхонегативного образования диаметром 2 мм с 10-го дня, а эмбриобласт в виде эхопозитивной полоски с 20-го дня после осеменения кобылы.

Через 14-16 дней после осеменения проводили контроль его результативности - плодное яйцо визуализировалось в правом роге матки размером 15 мм. Через 21-22 дня регистрировали сердцебиение у эмбриона. Через 30 дней после осеменения проводили контроль жеребости - визуализировали развивающийся эмбриОн. На 65-70-й день после осеменения с точностью до 90 \% определяли пол будущего жеребенка. При сроке жеребости более 150 дней плод достигает размера 26-38 см, принимает головное предлежание, и определить его пол методом трансректальной визуальной эхографии практически не представляется возможным.

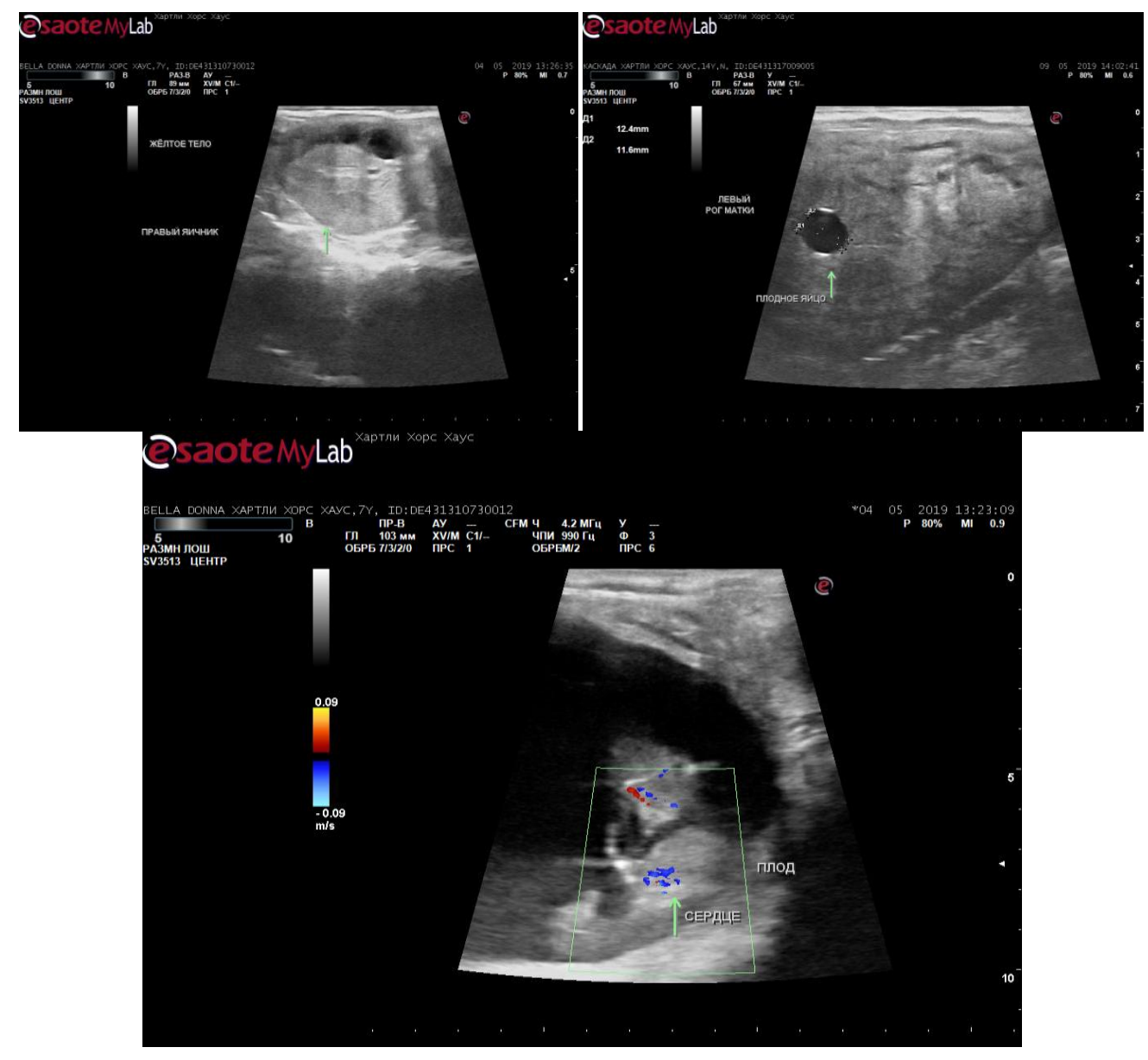

Puс. 2. Ультразвуковой мониторинг жеребости кобыл

Результаты исследования уровня прогестерона в крови кобыл в первые 1,5 месяца жеребости показали, что это величина индивидуальная и весьма вариабельна. Между 35-м и 45-м днями нормальной жеребости концентрация прогестерона в крови у кобыл возрастает. В среднем по груп- пе показатель составил 33,01 нмоль/л. У двух кобыл уровень прогестерона был понижен и составил соответственно 11,49 и 17,81 нмоль/л.

Был сделан вывод, что падение уровня прогестерона на указанном сроке может рассматриваться как угроза потери жеребости и основание 
для применения гормональной поддержки (прогестиновой терапии).

Заключение. В целях более успешной организации воспроизводства лошадей в центрах репродукции необходимо проводить комплексную оценку содержания, кормления кобыл с анализом структуры рациона и качества кормов, оценивать клинический статус животных после осеменения, применять метод трансректальной визуальной эхографии для ранней диагностики жеребости и морфометрической и фрункциональной оценки развития зародыша.

\section{Литература}

1. Андрюшин В.В. Воспроизводство лошадей: справочник. - М.: Колос, 2000. - С. 113-128.

2. Гнездилова Л.А., Курилова Н.М. Влияние балансирующей кормовой добавки «Богатырь» на показатели обмена веществ у спортивных лошадей // Вопросы нормативно-правового регулирования в ветеринарии. - 2019. - № 1. - С. 177-180.

3. Лебедева Л.Ф. Методы оптимизации технологии воспроизводства в племенном коневодстве: автореф. дис. ... д-ра ветеринар. наук. - Дивово, 2007. - 41 с.

4. Рождественская Г.А. Племенная работа в коневодстве. Практическое коневодство: справочник. - М.: Колос, 2000. - С. 47-54.

5. Bergfelt D.R., Woods J.A., Ginther O.J. Role of the embryonic vesicle and progesterone in embryonic loss in mares // J Reprod Fertil. 95:339-347-1992.

6. Allen W.R. (2005). Maternal recognition and maintenance of pregnancy in the mare. Anim Reprod, 2:209-223.

\section{Literatura}

1. Andryushin V.V. Vosproizvodstvo loshadej: spravochnik. - M.: Kolos, 2000. - S. 113-128.

2. Gnezdilova L.A., Kurilova N.M. Vliyanie balansiruyushchej kormovoj dobavki «Bogatyr'» na pokazateli obmena veshchestv u sportivnyh loshadej // Voprosy normativno-pravovogo regulirovaniya $v$ veterinarii. - 2019. - № 1. S. 177-180.

3. Lebedeva L.F. Metody optimizacii tekhnologii vosproizvodstva $\mathrm{v}$ plemennom konevodstve: avtoref. dis. ... d-ra veterinar. nauk. - Divovo, 2007. - $41 \mathrm{~s}$.

4. Rozhdestvenskaya G.A. Plemennaya rabota $\mathrm{v}$ konevodstve. Prakticheskoe konevodstvo: spravochnik. - M.: Kolos, 2000. - S. 47-54.

5. Bergfelt D.R., Woods J.A., Ginther O.J. Role of the embryonic vesicle and progesterone in embryonic loss in mares // J Reprod Fertil. 95:339-347-1992.

6. Allen W.R. (2005). Maternal recognition and maintenance of pregnancy in the mare. Anim Reprod, 2:209-223. 